\title{
Influence of detergent on metabolic activity of fungi Aspergillus niger
}

\author{
Jelica Stojanović ${ }^{1 *}$, Violeta Jakovljević ${ }^{1}$, Ivana Matović ${ }^{1}$, Olgica Gajović ${ }^{2}$, Zoran Mijušković ${ }^{3}$, \\ Tomislav Nedeljković
}

${ }^{1}$ Faculty of Science, University of Kragujevac, Kragujevac, Serbia; * corresponding author: jelica@kg.ac.rs

${ }^{2}$ Medical Faculty, University of Kragujevac, Kragujevac, Serbia

${ }^{3}$ Military Medical Academy, Belgrade, Serbia

Received 1 April 2011; revised 28 April 2011; accepted 10 May 2011.

\begin{abstract}
The aim of this study was to find out, among grate variety of fungi species from wastewater these which are resistant to effects of detergent and its component, ethoxyl-oleyl-cetyl alcohol and sodium tripolyphosphate. On inoculated fungi specie grown in vitro condition, in the presence of mentioned pollutant, the metabolic changes of bioproduction of different organic compounds, in various aging step of fungi, have been investigated. The results indicated significant changes in bioproduction of amino acids and proteins of Aspergillus niger cultivated in the presence of detergent and its component, compared with control experiment. The results suggest that bioremediation by Aspergillus niger are promising for biodegradation of detergents in aquatic systems.
\end{abstract}

Keywords: Aspergillus Niger; Detergent; Bioproduction; Wastewater; Biodegradation

\section{INTRODUCTION}

Detergents are formulations designed to have cleaning/solubilisation properties. These formulations consist of surface-active agents (surfactants) together with subsidiary components including builders (e.g. tripolyphosphate), boosters, filters and auxiliary compounds. Surfactants are a group of organic compounds achieved by chemical synthesis and characterized for specific behavior in solution that makes them especially suitable for many human activities. Surfactant is an abbreviation for a surface-active agent that refers to its ability to reduce the interfacial tension between two phases. This behavior is caused by the molecular composition in the surfactant, which has a hydrophobic part, composed of alkyl chains, and another part that is an anionic or hydro- philic group [1]

A massive stream of surfactants is directed to the aquatic environment. Surfactants are probably the largest supplier of artificial organic carbon to the aquatic environment [2]. Even though surfactants are essentially non-toxic to man at the concentrations likely to be met in wastewaters, there is wide agreement that their presence both in natural freshwater sources and in other ecosystems is undesirable. The principal criterion for the ecological behavior of surfactant is their biodegradability [3].

Many researchers fortified that microorganisms, particularly some kind of fungi, can act as potential degraders of detergents [4,5]. Among the fungi which have such ability, filamentous fungi (Deuteromicotina) are especially distinguished due to their physiological and biochemical characteristics [6]. Specificity in apical growth of these fungi enables penetration in solid substrates and excretion of extracellular enzymes from vesicles on the top of hyphae to environment. Under the influence of these enzymes complex organic compounds are decomposed to simpler which fungi can use for growth and development of mycelia and biomass accumulation [7-9].

The Aspergillus fungus was first recognized as an organism in 1729 by Micheli [10]. The genus Aspergillus is found worldwide and consists of more than 180 officially recognized species, and comprises a particularly important group of filamentous ascomycete species [11]. Although it includes the major filamentous fungal pathogen of humans, Aspergillus fumigatus [12], most of the members are useful microorganisms in nature for degradation of plant polysaccharides [13], and they are important industrial microorganisms for the large-scale production of both homologous and heterologous enzymes [14-18]. Among them, Aspergillus oryzae and Aspergillus niger are on the Generally Recognized as Safe list of Food and Drug Administration in the United 
States [19]. Aspergillus niger is one of the most important microorganisms used in biotechnology [20,21] which produces many extracellular enzymes.

Detergents have severe effects on wildlife and human health due to their toxicological properties [22]. Linear alkylbenzene sulphonate (LAS) is anionic surfactant most widely used as a major ingredient in domestic and industrial detergents. It can easily be degraded by microorganisms in wastewater treatment plants using aerobic processes [23,24], however the intermediates are less biodegradable [25]. Such metabolites may be toxic to higher biotrophic members of the ecosystem, but they also offer a potential carbon and energy source for microorganisms capable of breaking them down further. LAS degradation may be performed by specific microorganisms that use it as a sole carbon source [26] or as a co-metabolic transformation [27]. Balson and Felix [28] described biodegradation as the destruction of a chemical by the metabolic activity of microorganisms. When reviewing the literature concerning the degradation of surfactants it is apparent that studies quote figures for primary and/or ultimate biodegradation [29]. Primary degradation can be defined as to have occurred when the structure has change sufficiently for a molecule to lose its surfactant properties. Ultimate degradation is said to have occurred when a surfactant molecule has been rendered to $\mathrm{CO}_{2}, \mathrm{CH}_{4}$, water, mineral salts and biomass. Primary degradation of LAS on activated sludge is grater then 99\% [30-32]. Traces of LAS in natural waters and soil continuo rapid degradation (half-live of LAS is about $0.15-0.5$ days), but total biodegradation still requires several days [33-37].

Surfactants and water miscible organic solvents are frequently used to increase the bioavailability of environmental contaminants for degradation [38]. LAS is used as a mediator in polyaromatic hydrocarbons degradation catalyzed by the extracellular enzyme system of some fungi [39]. Also, it was found that addition of detergents have enhancing effects on extracellular production of some metabolites with microorganisms [40] and may be useful method for over-production of hydrophobic compounds by means of biological process.

Herein we describe our studies on influence of detergent on metabolic activity of fungi Aspergillus niger.

\section{MATERIAL AND METHODES}

The experiments were performed using monosporial culture of the fungi Aspergillus niger van Tiegheme isolated from the river Lepenica (Serbia) on wastewater outpouring site. Identification of the culture was done on Faculty of biology, Belgrade, in Laboratory for algae, fungi and lichens. Monosporial culture of the fungi was obtained by the method of exhaustion on a poor potato-dextrose agar [41].

The detergent powder used was packaged household synthetic detergent of domestic Merix brand (Merima, Kruševac). Ethoxyl-oleyl-cetyl alcohol and sodium tripolyphosphate are also supplied by Merima.

The method can be summarized as follows: fungi were inoculated into a flask that contained a chemically-defined microbial growth medium and the surfactant to be tested. The fungi were grown in the sterile liquid nutrient medium according to Czapek consisted of: $3 \mathrm{~g} \mathrm{NaNO}_{3}, 1$ $\mathrm{g} \mathrm{K}_{2} \mathrm{HPO}_{4}, 1 \mathrm{~g} \mathrm{MgSO}_{4}, 0.25 \mathrm{~g} \mathrm{MgSO}_{4} \times 7 \mathrm{H}_{2} \mathrm{O}, 0.01 \mathrm{~g}$ $\mathrm{FeSO}_{4} \times 7 \mathrm{H}_{2} \mathrm{O}$ and $30 \mathrm{~g}$ saccharose, dissolved in $1000 \mathrm{ml}$ of distilled water. Detergent designated D, ethoxyl-oleylcetyl alcohol (AOC) and sodium tripolyphosphate (TPP) was added (1\%) and the flasks incubated for 4-8 days. The flasks containing $200 \mathrm{~cm}^{3}$ of medium were uniformly and constantly shaken on Kinetor shaker at room temperature in condition of alternate light-dark cycles [42]. The sterility of the nutrient medium was tested using mesopeptone agar.

For the determination of free organic acids $10 \mathrm{ml}$ of medium was taken and mixed with $50 \mathrm{ml}$ of ethanol. After incubation at $70^{\circ} \mathrm{C}$ in a water bath for $1-1.5$ hours, the mixture was filtered through a special filter. The filtrate then was concentrate at $50^{\circ} \mathrm{C}-60^{\circ} \mathrm{C}$ and reduced pressure to the volume of $40 \mathrm{ml}$, transferred to a volumetric flask and made up to $100 \mathrm{ml}$ after addition of a teaspoon of the active charcoal. After standing in a water bath for $30-45 \mathrm{~min}$ at $70^{\circ} \mathrm{C}, 10 \mathrm{ml}$ aliquots of filtrate were taken for the determination of the free organic acids by titration with $0.1 \mathrm{M} \mathrm{NaOH}$ in the presence of phenolphthalein as indicator [43-45].

The monosaccharides, glucose and fructose, were determined after cation-exchange chromatography on a column of AmberliteIR-120 followed by descending chromatography on Whatman No 1 paper. After reaction with suitable reagent to produce a green-blue complex, the amount of glucose and fructose were determined spectrofotometrically using a red filter in comparison with the appropriate standard curves [43].

The qualitative and quantitative content of amino acids was determined by standard method described by Sparkman [46] using aminoanalyzer BECKMAN model $120 \mathrm{C}$. Measuring conditions: stationary phaseLiChroCART 250-4, mobile phase-0.10 M acetic buffer ( $\mathrm{pH} 4.4$ ) and acetonitrile in 70:30 ratio, mobile phase rate $1.0 \mathrm{ml} / \mathrm{min}$, fluorescent detector (Ex $263 \mathrm{~nm}$, Em $313 \mathrm{~nm}$ ).

The amount of proteins was determined by Kjeldahl method on the basis of amount of nitrogen present in fungi [47] using equation:

Amount of proteins $=6.25 \mathrm{x}$ amount of nitrogen $(\mathrm{mg})$ 


\section{RESULTS AND DISCUSION}

This paper conducted a research on influence of detergent Merix (Merima, Kruševac, Serbia) and its components (ethoxyl-oleyl-cetyl alcohol and sodium tripolyphosphate) on metabolic activity of fungi Aspergillus niger. The metabolic changes of bioproduction of different organic compounds in various aging step of fungi in the presence of pollutant has been investigated. This fungus was isolated from the river Lepenica (Serbia) on wastewater outpouring site and was chosen because it was the most abundant there. The fungi was then grown in the liquid nutrient medium according to Czapek, where $1 \%$ of detergent or its component was added, during the incubation period of 4-8 days after inoculation. Metabolic activity of Aspergillus niger grown in such liquid nutrient medium and control medium is monitored over following biochemical parameters: amounts of free organic acids and monosaccharides on 4th and 8th day of incubation period, amount of proteins on each day of incubation period and qualitative and quantitative content of amino acids on the last day of incubation period.

Aspergillus niger did not produce carbohydrates on the 4th day of incubation period. At the end of examination period, fungi produced different amount of carbohydrates (glucose and fructose) depending on the composition of nutrient medium. Compared with the control medium, production of fructose was increased in all version of nutrient medium, except in the case when $1 \%$ of detergent was added (Figure 1).

Production of free organic acids was increased in all cases at the end of experimental period, but it was dramatically increased in nutrient medium with sodium tripolyphosphate added (Figure 2).

On the last day of experimental trial, in the control nutrient medium Aspergillus niger produced 15 essential amino acids while in the nutrient medium with $1 \%$ of detergent added 14 essential amino acid were produced. The detergent manifested extremely stimulating effect on bioproduction of lysine, arginine, aspartic and glu-

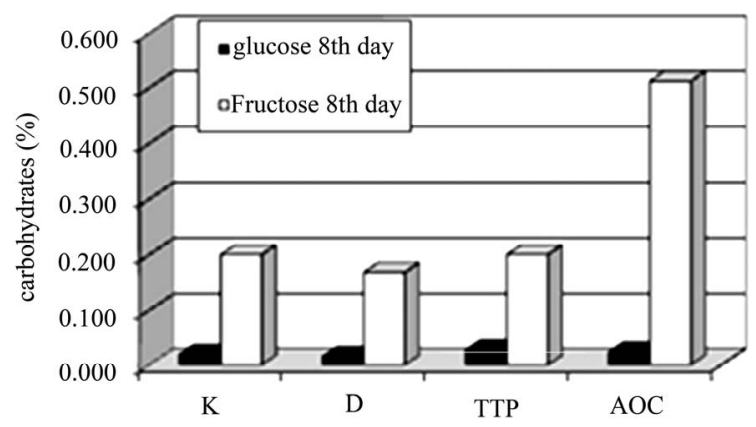

Figure 1. Amount of carbohydrates (\%) produced by $A$. niger on 8th day in different liquid nutrient mediums.

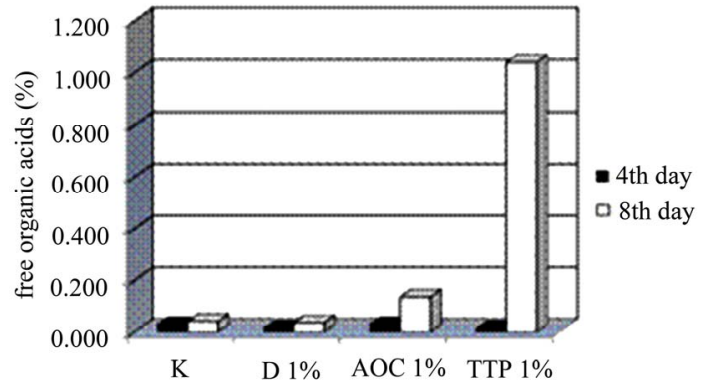

Figure 2. Amount of free organic acids (\%) produced by $A$. niger on the 4th and 8 th day in different liquid nutrient mediums.

tamic acid, valine, leucine, isoleucine and tyrosine. Bioproduction of other amino acids was less intensity, but still increased in comparison with those produced in control medium. Only alanine was not produced in the presence of detergent (Figure 3).

Amount of proteins produced by Aspergillus niger in different liquid nutrient mediums was monitored on each day of 4-8 days incubating period and had differed depending on the liquid nutrient medium used and the aging step of fungi (Figure 4).

With the aging of fungal culture production of pro-

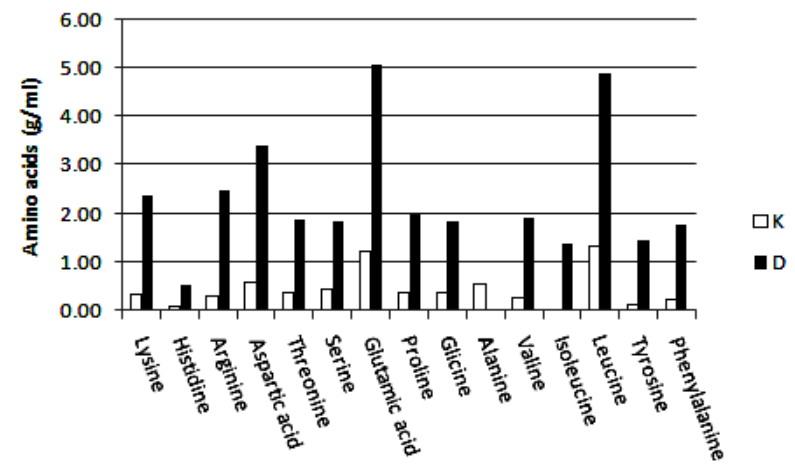

Figure 3. Qualitative and quantitative content of amino acids produced by $A$. niger on the 8 th day in liquid nutrient medium with $1 \%$ detergent added.

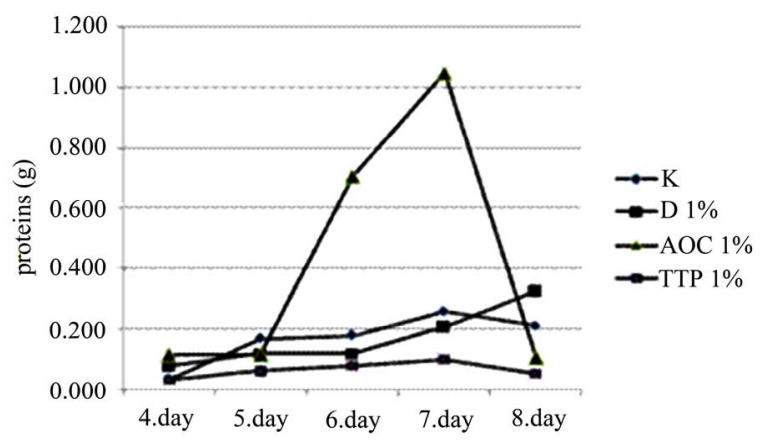

Figure 4. Amount of proteins (g) produced by A. niger during 4-8. day of incubating period in different liquid nutrient mediums. 
teins decreased in all cases, except in the medium with $1 \%$ of detergent added in which production was a little bit higher compared with control experiment. The highest production of proteins was in the medium with $1 \%$ ethoxyl-oleyl-cetyl alcohol added on 7th day, while the lowest was in the medium with $1 \%$ sodium tripoly- phosphate added on 4th day of incubation. Sodium tripolyphosphate exhibited the highest inhibitory effect on bioproduction of proteins during the entire incubation period.

\section{CONCLUSIONS}

On the basis of the results obtained it can be concluded that detergent and its components added to liquid nutrient medium according to Czapek changed metabolic activity of fungi Aspergillus niger on a different ways, what reflected on growth and development of fungi.

The results of amino acid analyses indicated that $\mathrm{As}$ pergillus niger is resistant to effect of detergent in concentration applied. It produced a variety of amino acids, 14 overall, and all of them were 2-10 times more abundant then in control experiment.

Bioproduction of proteins, at the end of examination period, was stimulated a little by detergent and extremely inhibited by sodium tripolyphosphate and partially by ethoxyl-oleyl-cetyl alcohol.

Detergent also exhibited high inhibitory effect on bioproduction of free organic acids while sodium tripolyphosphate and ethoxyl-oleyl-cetyl alcohol exhibited considerably stimulating effect.

Detergent powder and its components highly influence metabolic activity of Aspergillus niger. Thus this fungus, which is most abundant on wastewater outpouring site of river Lepenica, can metabolize detergent components for growth and biomass accumulation and play an important role in purification of river waters.

\section{REFERENCES}

[1] López-Mahia, P., Muniategui, S., Prada-Rodriguez, D. and Prieto-Blanco, M.C. (2005) Surfactants and detergents. In Worsfold P., Townshend A., Poole C. Eds. Encyclopedia of analytical science (Second Edition). Elsevier Science, London. doi:10.1016/B0-12-369397-7/00608-7

[2] Brunner, P.H., Capri, S., Marcomini, A. and Giger W. (1988) Occurrence and behavior of linear alkylbenzene sulphonates, nonylphenol, nonylphenol mono- and nonylphenol diethoxylates in sewage and sewage sludge treatment. Water Res, 22, 1465-1472. doi:10.1016/0043-1354(88)90157-1

[3] Cain, R.B. (1994) Biodegradation of detergents. Current Opinion in Biotechnology, 5, 266-274. doi:10.1016/0958-1669(94)90028-0

[4] Sanz, J.L., Culubret, E., De Ferrer, J., Moreno, A. and Berna, J.L. (2003) Anaerobic biodegradation of linear alkyl benzene sulfonate (LAS) in upflow anaerobic sludge blanket (UASB) reactors. Biodegradation, 14, 57 64. doi:10.1023/A:1023557915653

[5] Bonin, P., Cravo-Laureau, C., Michotey, V. and HirchlerRea, A. (2004) The anaerobic hydrocarbon biodegrading bacteria: An overview. Ophelia, 58, 243-254.

[6] Raimbault, M. (1981) Fermentation en milieu solide: croissance de champignons filamenteux sur substrats amylacés. Série Travaux et Documents, ORSTOM, Paris.

[7] Raimbault, M. (1998) General and microbiological aspects of solid substrate fermentation. Electronic Journal of Biotechnology, 1, 1-15.

http://www.scielo.cl/scielo.php?pid=S0717-345819

[8] Saucedo-Castañeda, G., Lonsane, B.K., Navarro, J.M., Roussos, S. and Raimbault M. (1992) Potential of using a simple fermenter for biomass built up, starch hydrolysis and ethanol production: Solid state fermentation system involving Schwanniomyces castellii. Applied Biochemistry and Biotechnology, 36, 47-61.

[9] Saucedo-Castañeda, G., Lonsane, B.K., Navarro, J.M., Roussos, S. and Raimbault, M. (1992) Maintenance of heat and water balances as a scale-up criterion for the production of ethanol by Schwanniomyces castellii in a solid state fermentation system. Process Biochemistry, 27, 97- 107. doi:10.1016/0032-9592(92)80016-V

[10] Micheli, P.A. (1729) Nova Plantarum Genera, Florentiae.

[11] Ward, O.P., Qin, W.M., Dhanjoon, J., Ye, J. and Singh, A. (2005) Physiology and Biotechnology of Aspergillus. Advances in Applied Microbiology, 58, 1-75. doi:10.1016/S0065-2164(05)58001-8

[12] Brookman, J.L. and Denning, D.W. (2000) Molecular genetics in Aspergillus fumigatus. Current Opinion in Biotechnology, 3, 468-474. doi:10.1016/S1369-5274(00)00124-7

[13] de Vries, R.P. (2003) Regulation of Aspergillus genes encoding plant cell wall polysaccharide-degrading enzymes; relevance for industrial production. Applied Microbiology and Biotechnology, 61, 10-20.

[14] Fawole, O.B. and Odunfa, S.A. (2003) Some factors affecting production of pectic enzymes by Aspergillus niger. International Biodeterioration \& Biodegradation, 52, 223-227. doi:10.1016/S0964-8305(03)00094-5

[15] Wang, L., Ridgway, D., Gu, T. and Moo-Young, M. (2005) Bioprocessing strategies to improve heterologous protein production in filamentous fungal fermentations. Biotechnology Advances, 23, 115-129. doi:10.1016/j.biotechadv.2004.11.001

[16] Mhetras, N.C., Bastawde, K. and Gokhale, D.V. (2009) Purification and characterization of acidic lipase from Aspergillus niger NCIM 1207. Bioresource Technology, 100, 1486-1490. doi:10.1016/j.biortech.2008.08.016

[17] Joseph, B., Ramteke, P.W. and Thomas, G. (2008) Cold active microbial lipase: some hot issues and recent development. Biotechnology Advances, 26, 457-470. doi:10.1016/i.biotechadv.2008.05.003

[18] Hasan, F., Shah, A.A. and Hameed, A. (2006) Industrial applications of microbial lipases. Enzyme and Microbial Technology, 39, 235-251. doi:10.1016/j.enzmictec.2005.10.016

[19] Tailor, M.J. and Richardson, T. (1979) Application of microbial enzymes in food systems and in biotechnology. 
Advances in Applied Microbiology, 25, 7-35. doi:10.1016/S0065-2164(08)70144-8

[20] Contesini, F.J., Lopes, D.B., Macedo, G.A., da Graca Nascimento, M. and de Oliveira Carvalho, P. (2010) Aspergillus sp. Lipase: Potential biocatalyst for industrial use. Journal of Molecular Catalysis B: Enzymatic, 67, 163-171. doi:10.1016/i.molcatb.2010.07.021

[21] Mitidieri, S., Martinelli, A.H.S., Schrank, A. and Vainstein, M.H. (2006) Enzymatic detergent formulation containing amylase from Aspergillus niger: a comparative stady with commercial detergent formulations. Bioresource Technology, 97, 1217-1224. doi:10.1016/j.biortech.2005.05.022

[22] Birkett, J.W. and Lester, J.N. (2003) Endocrine disrupters in wastewater and sludge treatment processes. CRC Press LLC, Florida.

[23] Ruiz Bevia, F., Prats, D. and Rico, C. (1989) Elimination of LAS (linear alkylbenzene sulfonate) during sewage treatment, drying and composting of sludge and soil emending processes. In: Quaghebeur D, Temmerman I, Angeletti G. Eds., Organic contaminants in waste water, sludge and sediment, Elsevier Applied Science, London.

[24] León, V.M., López, C., Lara-Martín, P.A., Prats, D., Varó, P. and González-Mazo, E. (2006) Removal of linear alkylbenzene sulfonates and their degradation intermediates at low temperatures during activated sludge treatment. Che- mosphere, 64, 1157-1166. doi:10.1016/j.chemosphere.2005.11.045

[25] Mehrvar, M. and Tabrizi, G.B. (2006) Combined photochemical and biological processes for the treatment of linear alkylbenzene sulfonate in water. Journal of Environmental Science and Health, Part A, 41, 581-597.

[26] Divo, C. and Cardini, G. (1980) Primary and total biodegradation of linear alkylbenzenesulfonates. Tenzide Det, 17, 30-36. doi:10.1016/S0043-1354(96)00191-1

[27] Hrsak, D. (1996) Cometabolic transformation of linear alkylbenzene-sulfonates by methanotrophs. Water $R e$ search, 30, 3092-3098.

[28] Balson, T. and Felix, M.S.B. (1995) The biodegradability of non-ionic surfactants. In: Karsa D R, Porter M R. Eds., Biodegradability of surfactants, Blackie Academic and Professional, New York.

[29] Scott, M.J. and Jones, M.N. (2000) The biodegradation of surfactants in the environment. Biochimica et Biophysica Acta, 1508, 235-251. doi:10.1016/S0304-4157(00)00013-7

[30] Mungray, A.K. and Kumar, P. (2008) Occurrence of anionic surfactants in treated sewage: risk assessment to aquatic environment. Journal of Hazardous Materials, 160, 362-370. doi:10.1016/i.jhazmat.2008.03.025

[31] Karahan, Ö. (2010) Inhibition effect of linear alkylbenzene sulfonates on the biodegradation mechanisms of activated sludge. Bioresource Technology, 101, 92-97. doi:10.1016/j.biortech.2009.07.088

[32] Moreno, A., Ferrer, J. and Berna, J.L. (1990) Biodegradability of LAS in a sewer system. Tenside Surfactants Detergents, 27, 312-315.

[33] EU Commission DGIII (1997) Study on the possible problems for the aquatic environment related to surfactants in detergents. WRC: EC, 4294
[34] Iltrich, N.R. and Federle, T.W. (1995) Primary and ultimate biodegradation of anionic surfactants under realistic discharge conditions in river water. SETAC Meeting, Vancouver, Canada.

[35] Küchler, T. and Schnaak, W. (1997) Behavior of LAS in sandy soils with low amounts of organic matter. Chemosphere, 35, 153-167. doi:10.1016/S0045-6535(97)00147-1

[36] Gledhill, W.E. (1975) Screening test of assessment of ultimate biodegradability: linear alkylbenzene sulphonates. App Environ Microbiology, 30, 922-929.

[37] Nomura, Y., Ikebukuro, K., Yokoyama, K., Takeuchi, T., Arikawa, Y., Ohno, S. and Karube, I. (1998) Application of linear alkylbenzene sulphonate biosensor to river water monitoring. Biosensors and Bioelectronics, 13, 10471053. doi:10.1016/S0956-5663(97)00077-8

[38] Kim, I., Park, J. and Kim, K. (2001) Enhanced biodegradation of polycyclic aromatic hydrocarbons using nonionic surfactants in soil slurry. Applied Geochemistry, 16, 1419-1428. doi:10.1016/S0883-2927(01)00043-9

[39] Pozdnyakova, N.N., Rodakiewicz-Nowak, J., Turkovskaya, O.V. and Haber, J. (2006) Oxidative degradation of polyaromatic hydrocarbons catalyzed by blue laccase from Pleurotus ostreatus D1 in the presence of synthetic mediators. Enzyme and Microbial Technology, 39, 1242- 1249. doi:10.1016/j.enzmictec.2006.03.009

[40] Muramatsu, M., Ohto, C., Obata, S., Sakuradani, E. and Shimizu, S. (2008) Various oils and detergents enhance the microbial production of farnesol and related prenyl alcohols. Journal of Bioscience and Bioengineering, 106, 263-267. doi:10.1263/jbb.106.263

[41] Gorlenko, M.V. and Sokolov, D.V. (1976) Plant growing. II, Prosvetenije, Moscow.

[42] Stojanović, J. (1990) Influence of detergent on biochemical properties of some fungi in vitro. Ph.D. Dissertation. Faculty of Science, Kragujevac.

[43] Veličković, D. (1971) Contribution to study of aminoacidic composition dynamics of protein complex and aminoacids in apple fruits during the vegetative period and storage. Ph.D. Dissertation. University of Belgrade, Belgrade.

[44] Stojanović, J., Stojanović, M. and Milovanović, A. (2001) Influence of detergent and some components of detergents on bioproduction of organic acids and enzymatic activity of fungi. Acta Veterinaria Beograd, 51, 171-176.

[45] Stojanović, J., Veličković, D. and Vučetić, J. (2002) Influence of detergent and some components of detergents on bioproduction of organic matter and enzymatic activity of two fungal species. Acta Veterinaria Beograd, 52, 267-272. doi:10.2298/AVB0204267S

[46] Sparkman, D.H., Stein, E.H. and Moore, S. (1958) Automatic recording apparatus for use in chromatography of amino acids. Analytical Chemistry, 30, 119.

[47] Petrović, S. and Petrović, J. (1971) Manual of Biochemistry. BIGZ, Belgrade. 